Ed. note: Buffalo Coulee, near Superb, Saskatchewan, was thus the third last nesting site of the Whooping Crane in Canada. Another nest was found about 10 miles to the northeast in the following year, May 19, 1922, by Neil Gilmour, and another some 30 or 35 miles NNE on May 28 - June 1, 1922, at Muddy Lake, 7 miles south of Unity, with one egg and one young collected. These were the last nests recorded until the discovery by W. A. Fuller, in
1954, of the Wood Buffalo Park nesting grounds.

We should like to suggest that the government prepare a sanctuary in one of the above areas, probably Muddy Lake, where in years to come some of the captive birds now being raised at the Patuxent Wildlife Research Center might be released into the wild in order to restablish themselves in their natural environment.

\section{EARLY WHOOPING CRANE NEST RECORDS NEAR YORKTON, SASKATCHEWAN}

\section{by C. Stuart Houston, 863 University Drive, Saskatoon}

Whooping Crane observations from 1890 to 1942 were given in my report on the birds of the Yorkton district, Saskatchewan (Can. Field-Nat., 63: 215-241, 1949), though nesting information was not cited.

R. P. Allen's comprehensive monograph on the Whooping Crane (Research Rep. No. 3, Natl. Audubon Soc., New York, 1952) listed seven Saskatchewan nest records: Moose Mountain, 1881; Battleford, 1884; Yorkton, 1900; north of Davidson, 1911; Bradwell, 1912; Baliol, 1922; and Muddy Lake near Unity, 1922.

The Yorkton record was substantiated by two eggs in the Thayer Collection, now in the Museum of Comparative Zoology at Harvard University, Cambridge, Massachusetts. I wrote to James C. Greenway, Jr., Curator of Birds, and his reply of April 7, 1954 stated that the label read as follows:

"From the Oological Coll. Walter

Raine, Toronto, Canada, Yorkton, No. Assiniboia, 16 May 1900. 2 eggs (Fresh). Collector: Cowboy

Brown.

"Nest: a mass of marsh hay on the prairie 3 feet in diameter, birds very wary, collector Cowboy Brown."

Greenway stated that these eggs could not be differentiated with certainty from eggs of the Sandhill Crane.
Enquiries to museums in eastern Canada and old-timers in the Yorkton area were made but the identity of "Cowboy Brown" was not established.

Further information concerning the probable nesting of Whooping Cranes in the Yorkton area was obtained from the Fernie brothers, both of whom farmed near Springside. About 1955, William Fernie told Cliff Shaw how he had settled first in the Wallace district northeast of Yorkton in 1883 and then moved to Springside in 1889. The last Whooping Crane Fernie had seen was a single young bird at Horseshoe Lake, "the year that Donald Gunn was flooded out." Several years prior to this, no doubt in the 1890's, Fernie had seen a Whooping Crane nest with two white eggs on top of a muskrat house on "Battersby's Lake" later known as "Scheller's Slough", between the old J. Carson ranch and Horseshoe Lake, on section 25 , township 28 , range 5 , six miles west of Gorlitz.

In addition, William Fernie told Cliff Shaw that in the spring the "whoop" call of the Whooping Crane could "be heard for five miles on a quiet morning." He saw no more than three birds together at any time, whereas Sandhill Cranes were much commoner and the Indians often made a meal of "a pot of potatoes and a young sandhill."

In late 1958, when Cliff Shaw gave me the notes of his interview with 